entirely escapes this objection either. Insofar as the aim of political theory is taken to be understanding, rather than prescription, the question of normativity is left hanging. Secondly, the hermeneutic idea of openness, the 'fusing of horizons' and his ecumenicism may indeed be preferable to 'monological preaching', but much may depend upon with whom we are engaging. Do we really want to enlarge our horizons to include the views of, say, white supremacists? This is not necessarily a rhetorical question, but it is the kind of issue that could usefully have been addressed.

Finally, we come to familiar problems of reflexivity, or 'performative contradictions', which typically bedevil this kind of enquiry. To give only one example (and it is not an isolated aberration): Vincent claims that 'There are no timeless truths, but rather timed and particular historically situated truths' (p. 323). But what then is the status of this claim? It sounds just like a 'timeless truth'. Or, if it is not, does this mean there could be other people at other times who did possess some timeless truths? And quite how would that be possible? I do not think that this kind of point can simply be dismissed as a cheap shot: it lies at the very heart of what this book about.

But nor would I want to end on this note. For Vincent has written an erudite, thoughtful and engaging book that everyone interested in questions of meta-theory should read. Moreover, in my view, in the conception of theory that he defends, he is certainly on the side of the angels; but the relative underdevelopment of his argument frustratingly means that the devil is still left with too many good tunes.

John Horton Keele University.

\title{
Democracy and Tradition
}

Jeffrey Stout

Princeton University Press, Princeton, 2004, 348pp.

ISBN: 0691102937.

\section{The Many and the One}

Richard Madsen and Tracy B. Strong (eds.)

Princeton University Press, Princeton, 2003, v $+372 p p$.

ISBN: 0691099936.

Contemporary Political Theory (2005) 4, 325-329. doi:10.1057/palgrave.cpt.9300191

Part of Stout's aim in Democracy and Tradition is to leave space for distinctively religious arguments in a liberal democratic polity, as against 
those theories that would deny such arguments a place in the public arena. This does not mean a rejection of liberal democracy per se and he attempts to provide a plausible alternative in what he calls a pragmatic Emersonian democratic tradition. The argument is conceptual, normative and also historical in that it addresses what he considers to be the state of America. In so doing he also addresses central questions of political theory.

Stout discusses two forms of liberalism in this context. That of Rawls, which holds that religious premises may be used in democratic deliberation but only if eventually arguments that appeal to a conception of justice that would be reasonable for reasonable people to accept are used. Secondly, the pragmatic liberalism of Rorty, who thinks the introduction of religious premises more or less guarantees the breaking off of an argument and should therefore be avoided. Rawls' argument is a principled one, an attempt to break from the vicious disruption that war over religion can and has caused. Rawls says, 'People can make arguments from the bible if they want to. But I want them to see that they should give arguments that all reasonable citizens might agree to. Again what's the alternative' (quoted in Stout, p. 72).

But this appears to marginalize those with religious views since they cannot be expected 'to be reasonably held by reasonable people' and so breeds a form of resentment. Stout sees this coming out in arguments which cast the liberal views above as secularist and/or incoherent. These 'new traditionalists' (as he calls them) are exemplified here by Hauerwas, Milbank and Alisdair MacIntyre. They argue that our ethical and political lives, and their rational narratives, only make sense within traditions. Liberalism cannot do this and indeed collapses the world into incoherence and nihilism in its attempt to provide a secular tradition. They thus deny 'secular reason', the converse of the liberal denial of 'religious reason.'

MacIntyre is the philosophical exponent of such thinking, normatively opting for some sort of Thomist-based tradition, whereas Hauerwas and Milbank produce theological arguments that are supportive of 'theological' as opposed to 'secular' reason, in that they stand against, for example, 1960's liberation theology not because of its political stance but because they see it as subordinating theology to secular reason. For them, liberal democratic arguments and liberal democracy itself are not part of a Christian message; that is something which can only be seen in its own terms, terms that liberal democracy cannot recognize. The church for Hauerwas should not engage in the arguments of liberal democracy but rather show by its life the paradigm Christian message of a non-violent response to conflict. This should be articulated in theological language and not the liberal language of rights.

Stout argues that whereas it might be right to reject Rawlsian or Rortian views as secularist ideology because they do not allow space for religious 
discourse, it does not follow that liberal democracy itself should be rejected. The new traditionalists do so because they believe the self-description of a liberal democratic society given by the theorists they attack. In so doing their only response, since those theorists' normative views (the banning of religious arguments from the public space) are not acceptable, is to disengage and think of themselves as an 'alien colony'; to prefer what Stout calls the 'enclave as a social form' (p. 115).

This, for Stout, is a mistake. One can see liberal democracy itself as a tradition and ethics as a social practise within that tradition. Key to Stout's argument is a careful analysis of MacIntyre's argument and especially his claim that liberalism cannot be a tradition. For Stout 'Liberalism transformed into tradition' is problematic only if you accept MacIntyre's description of liberalism. If you take another plausible description of the liberal project that is to 'tailor the political institutions and moral discourse of modern society to the facts of pluralism', we can see MacIntyre's characterization, the 'quest for standpoint above all tradition' and 'to abstract entirely from the common good' as merely two possible instantiations of that project. One or both can be rejected without rejecting the liberal project itself.

For Stout there are at least three commitments for someone concerned with the practice of an Emersonian democratic tradition: citizens ought to (a) enjoy equal standing in the democratic process, (b) have respect as individuals keeping track of discussion from their own distinctive point of view and (c) have a stake in expressive freedom through accepting constraints in a reflexive or dialectical manner; seeing them unfold in the process of applying and deciding upon normative concepts.

He carefully argues how seeing ethics as a social practice can be rooted in the contingencies of that practice without thereby losing its objectivity. Democratic ethical discourse is social not in giving the democratic community ultimate authority (the We against the I). Rather its social nature 'needs to be understood in terms of what the individual members of a group do when they keep track of their interlocutors' commitments from their own perspectives' ( $p$. 279). This implies that there is no privileged point of view, that of the community, but an exchange of views and reasons with members, always trying to get at the others' perspectives. It is in that exchange that community exists (an I-Thou model).

Although all communities have discursive practices that give authority to some because no community could function in any other way, they are not thereby authoritarian. For Stout, the only defensible form of democratic community is one where ethical authority is deferred to those who have proved themselves wise in ethical judgement. That authority is not earned by bowing to the will of the majority, rather it comes through the reflexive giving and receiving of reasons, of exposing one's views in fora where they have to 
withstand the critical scrutiny of all. And it is always defeasable. He gives an idea of what this might mean by the practice of the area where he himself lives and the interactions between races and cultures there. Here again there is no idealism but a realistic account of what it might mean to live in such a community, warts and all. Indeed the examples and illustrations he gives, many of them from his own experience, clarify and add to the quality of the book.

This is a timely and important book for it tries to rescue liberalism from those who feel excluded by it. The book is set in America and is partly about the possibilities of such democracy in America. Here again it is timely. For the new traditionalist reaction to the liberal Rawlsian view, while being politically progressive in many of the divinity schools, is also ammunition for an intolerant religious right which has at least partly taken political power in America. Stout's arguments allow a more pluralistic view where incommensurable arguments can feed on and fertilize each other. But he is not naïve about those possibilities or about American politics, and the book's conclusion is a powerful indictment of America's actions in the world, especially after 9/11; how this itself weakens the chance of expressive democracy taking root.

The Many and the One gives us an example of Stout's political and intellectual project in action. It is a collection of essays and responses where scholars ask how ethical pluralism can be understood by classical liberalism, liberal egalitarianism, critical theory, feminism, natural law, Confucianism, Islam, Judaism, and Christianity. A common set of questions are addressed: Should the state protect, ban or otherwise interfere in, ethical differences? How should disagreements on the rights and duties of citizens be dealt with? Should the state regulate life and death decisions? How should conflicting views on sexual relationships be accommodated? The book itself gives us a hopeful way forward in looking at how these differences might be understood and resolved.

In the introduction, Madsen and Strong distinguish three levels of pluralism: at the existential level, we are, as individuals, faced with having to choose between competing values but ones which we can recognizably see as our own. At the cultural level, the choice is between a wider range of values, some of which we might not see as our own but as from a different and alien culture. Here the challenge is, as Taylor puts it, '[how] can people bond not in spite of but because of difference' (quoted in Madsen and Strong, p. 11). This would be different from the sort of view which, like Rawls, too readily has an unquestioning assumption of the primacy of Enlightenment reason. At the level of civilization we are looking at the necessity of something like this in the world as a whole which has now become something not like a global village (for that has too many connotations of homogeneity) but rather a global city tied together in diversity.

MacIntyre described our condition as 'civil war carried out by other means'. But this view is not supported by the success of this book. There are many 
areas where views can be similar or overlap. What is important is what Moon, in the conclusion, calls perspectival pluralism; where traditions concentrate on reasonable disagreement and by so doing are perhaps more able to alter their own perspectives. Some traditions see this as their main point, but even those that are more comprehensive seem to have this potential built in (see, for example, the discussion of the role of conscience within Christianity). So there is hope, and the Ethikon Institute, under whose auspices the meeting which resulted in this book took place, is to be congratulated for facilitating this exchange.

All in all, these books are timely and essential reading for those who are interested in a civil and dispassionate, but nevertheless engaged look, at the problems of ethical and religious pluralism as they are presented today. They both make an excellent contribution.

Zenon Bankowski University of Edinburgh.

\section{The Political Economy of New Slavery}

Christien van den Anker (ed.)

Palgrave Macmillan, Basingstoke, 2004, xvi+272pp. ISBN: 1403915237.

Contemporary Political Theory (2005) 4, 329-331. doi:10.1057/palgrave.cpt.9300194

This collection of essays on contemporary slavery arises out of a workshop conducted by the Centre for the Study of Global Ethics at Birmingham University in May 2002 that brought the practical knowledge of campaigners together with academic critique. The contributors range from seasoned academics like Nigel Dower and Jeroen Doomernik to practitioners working in the field; the NGO Anti-Slavery International (ASI) is a marked presence, with the Foreword to the volume provided by Mary Cunneen, the director of ASI. While giving a needed voice to campaigners, the diversity of expertise of the contributors also makes for a mixed bag in terms of the quality of analysis in the essays; the best are those that combine academic nous with concrete application.

Van den Anker's immediate concern in putting together this wide rangingcollection is to demonstrate the applicability of the unifying concept of slavery to a number of abusive practices which have been previously studied under discrete headings: child labour, debt bondage, forced prostitution, migrant 